\section{Literature Cited}

Dunn, E.H. And E.L. Tessaglia. 1994. Predation of birds at feeders in winter. J. Field Ornithol. 65:8-16.

FARMER, G.C., K. MCCARTY, S. ROBERTSON, B. ROBERTSON, AND K.L. BII DSTEIN. 2006. Suspected predation by Accipiters on radio-tracked American Kestrels (Falco sparverius) in eastern Pennsylvania, U.S.A. J. Raptor Res. 40:294-297.

Petty, S.J, D.I.K Anderson, M. Davison, B. LITTLE, T.N. SherratT, C.J. Thomas, AND X. LAmbin. 2003. The decline of Common Kestrels Falco tinnunculus in a forested area of northern England: the role of predation by Northern Goshawks Accipiter gentilis. lbis 145:472-493.

YOSEF, R. 1995. Spring 1994 raptor and soaring bird migration at Eilat, Israel. J. Raptor Res. 29:127-134.
1996. Raptors feeding on migration at Eilat, Israel: opportunistic behavior or migratory strategy? J. Raptor Res. 30:242-246.

P. Tryjanowski, And K. Blldstein. 2002. Spring migration of adult and juvenile buzzards Buteo buteo through Eilat, Israel: timing and body size. J. Raptor Res. 36:115-120.

ZALLES, J.1., and K.L. BILDSTEIN. [EDS.]. 2000. Raptor watch: a global directory of raptor migration sites. BirdLife Conservation Series No. 9. BirdLife International and Hawk Mountain Sanctuary, Cambridge, U.K.

Received 11 August 2009; accepted 7 October 2009

J. Raptor Res. 44(1):78-79

(C) 2010 The Raptor Research Foundation, Inc.

\title{
First Record of Rabbit Carrion Consumption by Elrasian Eagle-Owl (Bubo bubo) on the IBERIAN PENINSUla
}

\author{
KEY WORDS: Eurasian Eagle-Owl, Bubo bubo; carrion consumption; European rabbit, feeding behavior.
}

The Eurasian Eagle-Owl (Bubo bubo) is a sit-and-wait predator (Cramp 1985) that captures a wide range of prey, from beetles (Order Coleoptera) to roe deer (Capreolus capreolus) fawns (Mikkola 1983). The diet of the eagleowl has been well documented in Europe (Foerstel 1977, Leditznig et al. 2001, Wassink 2003), and in Mediterranean ecosystems of the Iberian peninsula, the species seems to specialize on rabbits (Oryctolagus cuniculus; Hiraldo et al. 1975, Serrano 1998, Martinez and Calvo 2001, Martinez and Zuberogoitia 2001).

The diet of this species is usually assessed by analysis of pellets and/or food remains (Marchesi et al. 2002), and this makes it difficult to determine if prey were captured alive or taken as carrion. Wassink (2003) suggested the possible occurrence of scavenging by eagle-owls after finding roe deer remains in eagle-owl nests in the Netherlands. Although other raptors on the Iberian peninsula use carrion, including that of the European rabbit (Hiraldo et al. 1991, Ferrer 2001), consumption of rabbit carrion has not been reported for eagle-owls.

During May 2008 we conducted an investigation of red fox (Vulpes vulpes) den sites in the natural park of Lagunas de Ruidera, central Spain $\left(38^{\circ} 56^{\prime} \mathrm{N}, 2^{\circ} 52^{\prime} \mathrm{W}\right)$. We distributed 26 carcasses of dead domestic rabbits evenly across an area of 1500 ha. A radiotransmitter (TW3-single celled, 10 g, Biotrack, Dorset, U.K.) was attached to each rabbit carcass and this allowed us to locate the carcasses with the help of a radio-receiver. Baits were hidden under trees and shrubs, to minimize the likelihood they would be detected and displaced by wild boars (Sus scrofa) or raptors.

Several days after placing the carcasses, we found one of the carcasses displaced about $150 \mathrm{~m}$ from its initial location. Upon investigation, we found the radiotransmitter inside a pellet near an eagle-owl nest occupied by a nestling that we estimated to be $30-35$ d old based on Penteriani et al. (2005).

Although some researchers have reported the consumption by eagle-owls of carrion from ungulates and farm chickens (Gallus domesticus) on the Iberian peninsula (Hiraldo et al. 1975, Real et al. 1985, Serrano 2000), the consumption of rabbit carrion had not been reported for this species (Donázar 1989, Serrano 1998, Martínez and Calvo 2001, Martínez and Zuberogoitia 2001, Lourenço 2006).

Our observation occurred in spring, during the eagleowl breeding season, when the availability of prey is greater than in other seasons. In contrast, raptors such as the Golden Eagle (Aquila chrysaetos) and Spanish Imperial Eagle ( $A$. adalberti) mainly consume carrion outside the breeding season (Watson 1997, Ferrer 2001), when food resources are likely comparatively scarce. We think it is likely the eagle-owl found the rabbit carcass in a "familiar" location near its nest and, taking advantage of low-cost food, fed the carcass to its young. This would explain why rabbit carrion was consumed during a period in which other prey was abundant. The consumption of carrion by the eagle-owl may be related to a behavior known in this (V. Penteriani pers. comm.) and other owl species (Vander 
Wall 1990), in which prey is sometimes cached and consumed at a later time. Our observation suggests that scavenging is an uncommon behavior in the eagle-owl.

We acknowledge the managers and forest rangers of the Natural Park of Lagunas de Ruidera for their authorization and support for the fieldwork, and especially to Manuel López for his invaluable and selfless help. We especially thank Miguel Delibes-Mateos, Fabian Casas, and Jesus Caro for their valuable comments on a previous version of the manuscript. This work was funded by the research projects CGL2005-02340/BOS and CGL2009-1074l from the Spanish $\mathrm{I}+\mathrm{D}$ National Plan and cofinanced with FEDER funds. JFdS was supported by a FPI grant funded by European Social Funds and the Spanish Ministry of Science and Innovation. Comments provided by V. Penteriani, I. Zuberogoitia, J.B. Buchanan, and an anonymous referee improved the manuscript.-Francisco Diaz-Ruiz (email address: Francisco.Druiz@uclm.es), Francisco Buenestado, Javier Fernández-de-Simón, and Pablo Ferreras, Instituto de Investigación en Recursos Cinegéticos, IREC (CSIC-UCLM-JCCM), Ronda de Toledo S/N, 13071 Ciudad Real, Spain.

\section{LITERATURE Cited}

Cramp, S. 1985. The birds of the western Palearctic, Vol. IV Oxford University Press, Oxford, U.K.

DONÁZAR, J.A. 1989. Variaciones geográficas y estacionales en la alimentación del Búho Real (Bubo bubo) en Navarra. Ardeola 36:25-39.

Ferrfr, M. 2001. The Spanish Imperial Eagle. Lynx Edicions, Barcelona, Spain.

Foerste., A. 1977. The Eagle Owl (Bubo bubo) in the Franconian forest and in the Bavarian Vogtland upper saxonian salle. Anz. Ornithol. Ges. Bayern 16:115-132.

Hirai do, F., J. Andrada, and F.F. Parreño. 1975. Diet of the Eagle Owl (Bubo bubo) in Mediterranean Spain. Doñana Acta Vert. 2:161-177.

J.C. BLanco, AND J. Bustamante. 1991. Unspecialized exploitation of small carcasses by birds. Bird Study $38: 200-207$.
LEDITZNIG, C., W. LEDITZNIG, AND H. Gossow. 2001. 15 years of investigations on the Eagle Owl (Bubo bubo) in the Mostviertel (Lower Austria, Austria). Egretla 44:45-73.

Lourenco, R, 2006. The food habits of Eurasian Eagle Owl in southern Portugal. J. Raptor Res. 40:297-300.

Marchesi, L., P. Pedrini, ANd F. Sergio. 2002. Biases associated with diet study methods in the Eurasian Eagle Owl. J. Raptor Res. 36:11-16.

Martíne7, J.E. and J.F. Calyo. 2001. Diet and breeding success of Eagle Owl in southeastern Spain: effect of haemorrhagic disease. J. Raptor Res, 35:259-262.

MARTÍNEZ, J.A. ANI I. ZUBFROGOITIA. 2001. The response of the Eagle Owl (Bubo bubo) to an outbreak of the rabbit haemorrhagic disease. J. Ornithol. 142:204-211.

Mikkola, H. 1983. Owls of Europe. T. and A.D. Poyser, Calton, U.K

Penterlani, V., M. Delgado, G. Maggio, A. Aradis, avi F. SERGIO. 2005. Development of chicks and predispersal behaviour of young in the Eagle Owl Bubo bubo. Ibis 147:155-168.

Real, J., A. Galobart, AND J. Fernavdez. 1985. Estudi preliminary d'una població de duc Bubo bubo al Vallés I Bages. El Medi Natural del Vallés. I Colloqui de Naturalistes Vallesans. Ann. CEEM 1:175-187.

SerRaNO, D. 1998. Diferencias interhábitat en la alimentación del Búho Real (Bubo bubo) en el valle medio del Ebro (NE de España): efecto de la disponibilidad de conejo (Ondolagus runiculus). Andeola 45:47-53.

. 2000. Use of farm chicken carcasses by the Eagle Owl. Ardeola 47:101-103.

VANDER WAL.L, S.B. 1990. Food hoarding in animals. University of Chicago Press, Chicago, IL U.S.A.

Wassink, G. 2003. First breeding of Eurasian Eagle Owl $B u b o$ bubo in the Achterhoek, eastern Netherlands. Limosa $76: 1-10$.

Watson, J. 1997. The Golden Eagle. T. and A.D. Poyser, London, U.K.

Received 30 March 2009; accepted 15 November 2009 Associate Editor: Joseph B. Buchanan 